\title{
MENTAL HEALTH DURING THE COVID-19 QUARANTINE IN FIVE COUNTRIES
}

\author{
Erika Yohanna BEDOYA CARDONA ${ }^{1}$, Ioana POPA², Anna MORANDI², Cristina MONTOMOLI ${ }^{2}$ \\ 1 University Cooperativa of Colombia, Colombia \\ 2University of Pavia, Italy
}

Corresponding author: Erika Yohanna Bedoya Cardona, e-mail: erika.bedoyac@campusucc.edu.co

DOI: $10.38045 /$ ohrm.2021.4.06

CZU: 616.89:616.98:578.834.1

Keywords: mental health, COVID-19, quarantine, pandemic.
Cuvinte cheie: sănătate mintală, pandemie.
Introduction. As part of the holistic concept of health, mental health can be focused on prevention of contagion and coping with the disease and its consequences in the context of the current COVID-19 pandemic. The present study describes, compares, and analyzes the association of the impact of the event, perceived stress, coping strategies, emotional regulation, and sociodemographic characteristics during the quarantine in various countries.

Material and methods. This research is a multicentric and epidemiological study with a convenience online snowball sampling of the general population and university students.

Results. 1.179 participants from Colombia, Brazil, Mexico, Italy, and Spain responded to the survey. Most of them included students and workers, with a high educational level and living with family during the quarantine. There are significant differences in the medians of all variables among countries and sociodemographic characteristics. The variables positively and significantly associated with the impact of the event during quarantine included the perceived stress, the coping strategies of alcohol/drug use, planning and active coping, focus on emotions and vent, the emotional regulation strategy expressive suppression, and living in Italy.

Conclusions. These results have contributed to the understanding of mental, emotional, and behavioral response to quarantine, as well as underline the urgency of monitoring mental health among the vulnerable groups, in order to design specific prevention and intervention programs.

\section{SĂNĂTATEA MINTALĂ ÎN TIMPUL CARANTINEI COVID-19 ÎN CINCI ȚĂRI}

Introducere. Ca parte a conceptului holistic de sănătate, în actuala pandemie COVID-19, sănătatea mintală presupune prevenirea contagiunii și gestionarea bolii și a consecințelor acesteia. Prezentul studiu descrie, compară și analizează asocierea impactului evenimentului, stresului perceput, strategiilor de adaptare, reglării emoționale și a caracteristicilor sociodemografice în timpul carantinei în diferite țări.

Material si metode. Studiu epidemiologic multicentric, cu o eșantionare convențională de tipul „bulgări de zăpadă” online a populației generale și a studenților universitari.

Rezultate. A fost realizat un sondaj la care au participat 1.179 de respondenți din Columbia, Brazilia, Mexic, Italia și Spania. Majoritatea dintre ei sunt studenți și muncitori, cu un nivel ridicat de educație, care au locuit cu familia în timpul carantinei. Există diferențe semnificative între medianele tuturor variabilelor între țări și caracteristici sociodemografice. Variabilele asociate pozitiv și semnificativ, cu impactul evenimentului în timpul carantinei, includ: stresul perceput, consumul de alcool/droguri, planificarea și gestionarea activă, concentrarea asupra emoțiilor, strategia de reglare emoțională, suprimarea expresivă și locuirea în Italia.

Concluzii. Aceste rezultate contribuie la întelegerea reactiilor mintale, emotionale si comportamentale în timpul carantinei și relevă necesitatea monitorizării urgente a sănătătii mintale în grupurile vulnerabile în scopul proiectării unor programe specifice de prevenire și de intervenție. 


\section{INTRODUCTION}

In the current COVID-19 pandemic, governments responded urgently to the biological threat and economic concerns, however, little effort has been directed to the mental health of the general population (1), which is part of the holistic concept of health, even though it is well known that experiences of quarantine can generate mental health effects (2-10). For example, during the 2003 severe acute respiratory syndrome (SARS) Sim et al. (11), in a study on the general population in Singapore found that psychiatric morbidity was associated with being put in fever stations, younger age, increased sense of guilt, and less substance use, while post-traumatic morbidity was associated with greater use of the coping strategies as denial and planning. On the other hand, Main et al. (12) showed that the number of stressors and the use of avoidance coping strategies positively predicted psycho-logical symptoms. Active coping positively predicted life satisfaction when controlling for stressors. Additionally, all types of coping served as a buffer against the negative impact of stressors on perceived overall health. During the 2015 Middle East respiratory syndrome (MERS) epidemic, Khalid et al. (13) investigated emotions, perceived stressors, and coping strategies in healthcare personnel working in a hospital in Jeddah (Saudi Arabia), finding that as a coping strategy, positive attitudes in the workplace, clinical improvement of infected colleagues, and interruption of disease transmission among healthcare workers after taking strict protective measures eased their fear.

The complexity of the COVID-19 pandemic worldwide, the socio-economic, political, and cultural situation in every single country, where there are many differences in terms of contagion containment measures, restrictions, laws, and sanctions, government and health authorities' management of the situation, type of information disseminated by media, resources available for diagnoses, treatments, and aid, number of infections and deaths, job and economic losses, etc., leads us to wonder about the psychological impact of the quarantine measures and all their implications. For example, during the initial stage of the outbreak, Wang et al. (14) showed that female gender, being a student, physical symptoms (e.g. myalgia, dizziness, coryza), and poor health were significantly associated with a higher psychological impact, stress, anxiety, and depression. Up-to-date and accurate specific health information (e.g. on treatment and on the local outbreak situation), and particular precautionary measures (e.g. hand hygiene and wearing a mask) were associated with a lower psychological impact, stress, anxiety, and depression. Therefore, it is important to know the perception, beliefs, emotions, and reactions regarding quarantine, since a measure of such a magnitude and length of time, even if it is taken for the good of the population, can usually generate psychological distress (15).

To date, most of the studies on the subject carried out in Asian, North American, European, and Australian countries are retrospective, have evaluated compliance with quarantine measures using ad-hoc scales, and used standardized scales to measure psychological variables, in healthcare personnel, in specific populations subjected to isolation, and in university students. The present study differs from other studies as it seeks to compare the impact of the event, perceived stress, coping strategies, emotional regulation as components of mental health, and sociodemographic characteristics such as gender, age, education level, occupation, and cohabiting during the first phase of the COVID-19 quarantine, in a sample of the general population and university students from various countries in Europe and Latin America.

\section{MATERIAL AND METHODS}

An observational and multicentric study was carried out by Universities in Colombia, Italy, Spain, Mexico, Brazil, and an international NGO (Spain). The type of sampling was a nonprobabilistic snowball since a digital questionnaire was sent through a link by email, WhatsApp, Instagram, Facebook, etc. Participants were asked to share the link with their contacts. Data were collected in all the countries involved between April and June 2020. Online consent was obtained from participants. The survey was anonymous, and confidentiality of information was assured. Since the online questionnaire design contained the forced answering option, there are no missing data.

The survey was completed by 1.179 participants (27.48\% male) aged between 15 to 76 years $(\mathrm{M}=33.52, \mathrm{SD}=13.4)$ from Colombia $(\mathrm{N}=356)$, 
Brazil ( $\mathrm{N}=364)$, Mexico ( $\mathrm{N}=202)$, Italy $(\mathrm{N}=166)$, and Spain $(\mathrm{N}=91)$. The first part of the digital questionnaire contained socio-demographic questions about gender, age, education level, occupation, and cohabiting during the first phase of the COVID-19 quarantine. Then the following instruments were included:

1. The Impact of Event Scale-Revised (IES-R; $16-18)$ is a 22 -item self-report scale designed to assess current subjective distress resulting from a traumatic life event, which in the current study corresponded to quarantine. The Cronbach's alphas in the present study for the total scale in the total sample and the Spanish version were .95 , for the Portuguese and Italian versions were 94 . For the subscales, the Avoidance Cronbach's alphas for the total sample and the Portuguese version were .85, for the Spanish version was .87, and for the Italian version was .80. The Intrusion Cronbach's alphas for the total sample and the Portuguese version were .90, for the Spanish version was .91, and for the Italian version was .89. And the Hyperarousal Cronbach's alphas for the total sample, the Spanish and Portuguese versions were .87 , and for the Italian version was 86 .

2. The Perceived Stress Scale (PSS-14 items; 19-21) contains 14 items assessing perceived stress in unexpected situations during the last month. The Cronbach's alphas for the total sample and all versions in the three languages were 87.

3. The Coping Orientations to Problems Experienced (COPE; 22, 23) contains 60 items evaluating 15 coping strategies. The Cronbach's alpha for the total scale in the total sample was .87, for the Spanish version .89 , Italian version .85 , and Portuguese version 88. While for the subscales, Cronbach's alphas range from .77 to .95 for the total sample, .76 to .95 for the Spanish version, .74 to .96 for the Italian version, and .71 to .95 for the Portuguese version.

4. The Emotion Regulation Questionnaire (ERQ; 24-26) is a self-report questionnaire that consists of two scales corresponding to two emotional regulation strategies: Cognitive reappraisal (6 items) and expres sive suppression (4 items). The Cronbach's alpha for the total sample was .79, for the Spanish version was .78, Portuguese and Italian versions were .80 . For the subscales, the Cognitive reappraisal Cronbach's alphas for the total sample and the Spanish version were.71, for the Portuguese version was .73, and for the Italian version was .75. The Expressive suppression Cronbach's alphas for the total sample was .87, for the Portuguese version was .86, and for the Spanish and Italian versions were 88 .

Cronbach's alpha was calculated to estimate the internal consistency of the scales and subscales in the total sample and the three versions by language. Normality tests were performed to identify the type of distribution of each variable (Kolmogorov-Smirnov), finding that none of them exhibited a normal distribution. Then, nonparametric statistics were performed. To compare differences in medians, Kruskal-Wallis tests with posthoc pairwise comparisons using Dunn's test with Bonferroni correction were employed. Spearman correlations were used to explore the relationship between the different variables. Finally, to analyze the association of the impact of the event (as a continuous variable) with perceived stress, coping strategies, emotional regulation, and socio-demographic variables, Generalized Linear Models (GLM) were employed. These are an extension of linear models that allow the use of non-normal distributions and nonconstant variances, with a Gaussian distribution and link = Identity. The final multivariate GLM was selected by using the lowest Akaike's Information Criterion (AIC), the normal residual distribution, and the inflation factor of variance (VIF) to verify the absence of multicollinearity in post-estimation tests. In all analyses $p<.05$ was considered statistically significant. Analysis was performed using the STATA 16 Software.

\section{RESULTS}

Table 1 shows that the greatest part of the sample is made of women, youth, and adults, with a high level of education, most of whom are devoted to studying and working, and the majority were living with family during the quarantine period.

In the present study, all the instruments pre sented good internal consistency. Nevertheless, since for the comparison of groups, Cronbach's 
Table 1. Distribution of the study population by sociodemographic characteristics and countries.

\begin{tabular}{lcccccc}
\hline \multicolumn{1}{c}{ Variables } & $\begin{array}{c}\text { Total Sample } \\
\mathbf{N ( \% )}\end{array}$ & \multicolumn{5}{c}{$\begin{array}{c}\text { Countries } \\
\mathbf{N}(\%)\end{array}$} \\
\cline { 3 - 7 } & & Colombia & Brazil & Mexico & Italy & Spain \\
\hline Gender & & & & & & \\
\hline Male & $324(27.5)$ & $113(31.7)$ & $83(22.8)$ & $53(26.2)$ & $38(22.9)$ & $37(40.6)$ \\
\hline Female & $855(72.5)$ & $243(68.3)$ & $281(77.2)$ & $149(73.8)$ & $128(77.1)$ & $54(59.3)$ \\
\hline Age (Years) & & & & & & \\
\hline $15-44$ & $693(58.8)$ & $211(59.3)$ & $196(53.8)$ & $146(72.3)$ & $96(57.8)$ & $44(48.4)$ \\
\hline $45-76$ & $486(41.2)$ & $145(40.7)$ & $168(46.1)$ & $56(27.7)$ & $70(42.2)$ & $47(51.6)$ \\
\hline Education Level & & & & & & \\
\hline Elementary/High school & $311(26.4)$ & $81(22.8)$ & $57(15.7)$ & $46(22.8)$ & $80(48.2)$ & $47(51.6)$ \\
\hline $\begin{array}{l}\text { Professional } \\
\text { Postgraduate }\end{array}$ & $868(73.6)$ & $275(77.2)$ & $307(84.3)$ & $156(77.2)$ & $86(51.8)$ & $44(48.4)$ \\
\hline Occupation & & & & & & \\
\hline Student \& worker & $534(45.3)$ & $169(47.5)$ & $136(37.4)$ & $127(62.8)$ & $70(42.2)$ & $32(35.2)$ \\
\hline Worker \& Other & $645(54.7)$ & $187(52.5)$ & $228(62.6)$ & $75(37.1)$ & $96(57.8)$ & $59(64.8)$ \\
\hline Live with & & & & & & \\
\hline Family & $1106(94.1)$ & $341(95.8)$ & $339(94.2)$ & $201(99.5)$ & $141(84.9)$ & $84(92.3)$ \\
\hline Alone or Roommates & $69(5.9)$ & $15(4.2)$ & $21(5.8)$ & $1(0.5)$ & $25(15.0)$ & $7(7.7)$ \\
\hline
\end{tabular}

alpha values from 0.7 to 0.8 are considered satisfactory (27), in the present study only the COPE subscales with values above .70 have been used for analysis. In Table 2, it can be seen that there are significant differences in all variables between all countries, except in cognitive reappraisal. The medians of the impact of the event are lower in Colombia and Mexico. The median of perceived stress in Colombia is lower than in the other countries. Also, the median of perceived stress in Mexico is lower than in Brazil. Concerning differences in the medians of coping strategies, Brazil's median of seeking social support is higher than Colombia, Mexico, and Spain. The medians show that turning to religion is less used in European countries; humour is less used in Colombia and Mexico than in Spain; alcoholdrug use in Colombia is lower than in Brazil and Italy; planning and active coping is most used in Colombia and Brazil; focusing on emotions and vent is higher in Brazil; positive reinterpretation is higher in Colombia. Finally, the expressive suppression emotional regulation strategy is higher in Spain.

Table 3 shows that there are significant differences for almost all the socio-demographic characteristics, except among cohabiting groups for which differences were found only in turning to religion and expressive suppression (higher medians in those living with family). The medians of the impact of the event, perceived stress, and focus on emotions and vent are higher in women, people under 45 years, with low educational levels, and students. At the same time, seeking for social support and turning to religion is higher in women, adults over 45 years, with high educational level, being workers and other (housewives and pensioners), and the same for positive reinterpretation and cognitive reinterpretation, except for the gender for which there were no differences. On the other hand, the medians of humor are higher in men with a high educational level, while the consumption of alcohol or drugs is higher in young men. Planning is higher in men, adults, with a high educational level, workers and other (housewives and pensioners). Finally, expressive suppression is higher in men who live with relatives.

Spearman's correlations among the Impact of Event with Perceived Stress, Coping Strategies, and Emotional Regulation were made. The positive correlations with perceived stress, social support, alcohol and drug use, focus on emotion and vent, and expressive suppression; and the negative correlations with religion, planning, positive reinterpretation, and cognitive reappraisal correspond to what is theoretically expected It was found that only Humour does not present a statistically significant correlation with the Impact of the event, while moderate and weak, but statistically significant correlation coefficients were found with the other variables (tab. 4). There was no multicollinearity among variables. 
Table 2. Comparison of medians (IQR) of Impact of the Event, Perceived Stress, Coping Strategies, and Emotional Regulation by Countries

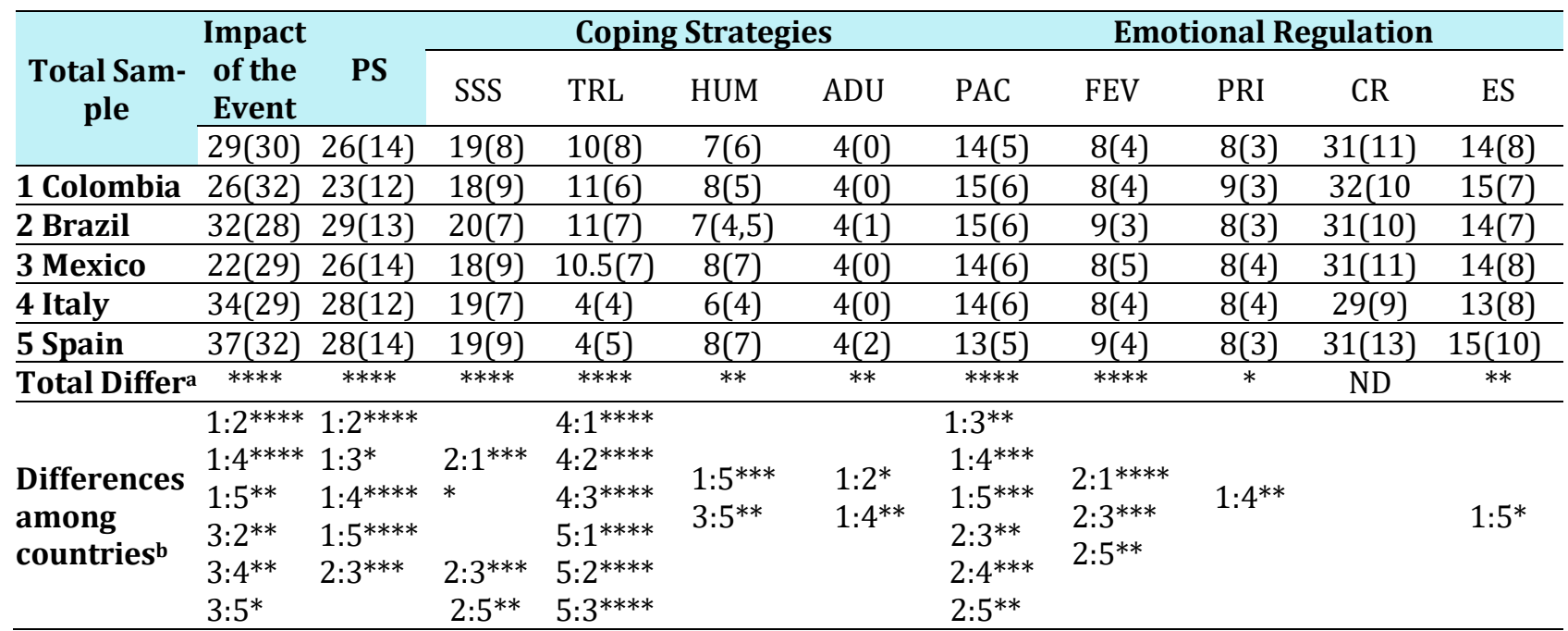

Note: aKruskal Wallis; bDunntest with Bonferroni correction; ${ }^{* * * *} p<.0001 .{ }^{* * *} p<.001 .{ }^{* *} p<.01 .{ }^{*} p<.05$.

IQR - Interquartile range; PS - Perceived Stress; SSS - Seeking social support; TRL - Turning to Religion; HUM Humour; ADU - Alcohol-drug use; PAC - Planning and active coping; FEV - Focus on emotions and vent; PRI Positive reinterpretation; CR - Cognitive Reappraisal; ES - Expressive Suppression; TD - Total Difference; ND - No Differences

Table 3. Comparison of medians (IQR) of Impact of the Event, Perceived Stress, Coping Strategies, and Emotional Regulation by Sociodemographic Characteristics.

\begin{tabular}{|c|c|c|c|c|c|c|c|c|c|c|c|}
\hline \multirow{2}{*}{$\begin{array}{c}\text { Socio- } \\
\text { demographic } \\
\text { Characteris- } \\
\text { tics }\end{array}$} & \multirow[b]{2}{*}{$\begin{array}{l}\text { Impact of } \\
\text { the Event }\end{array}$} & \multirow[b]{2}{*}{ PS } & \multicolumn{5}{|c|}{ Coping Strategies } & \multicolumn{4}{|c|}{ Emotional Regulation } \\
\hline & & & SSS & TRL & HUM & ADU & PAC & FEV & PRI & CR & ES \\
\hline Gender & $* * * *$ & $* * * *$ & $* * *$ & $* * * *$ & $* * * *$ & $* *$ & $* *$ & $* * * *$ & ND & ND & $* * * *$ \\
\hline Male & $24(30)$ & $23(12)$ & $18(7.5)$ & $9(8)$ & $8(6)$ & $4(1)$ & $15(6)$ & $8(3)$ & $8(3)$ & $30(11.5)$ & 15.5(8) \\
\hline Female & $32(30)$ & $28(13)$ & $19(7)$ & $10(8)$ & $7(5)$ & $4(0)$ & $14(5)$ & $9(4)$ & $8(3)$ & $31(10)$ & $14(7)$ \\
\hline Age (Years) & $* * * *$ & $* * * *$ & ND & $* * * *$ & ND & $* *$ & $* * * *$ & $* * * *$ & $* * * *$ & $* * * *$ & ND \\
\hline$(15-44)$ & $33(32)$ & $29(13)$ & $18(8)$ & $9(9)$ & $7(6)$ & $4(1)$ & $14(6)$ & $9(4)$ & $8(3)$ & $30(11)$ & $14(8)$ \\
\hline$(45-76)$ & $25(27)$ & $22(12)$ & $19(7)$ & $11(6)$ & $7(6)$ & $4(0)$ & $16(5)$ & $8(3)$ & $9(3)$ & $32(9)$ & $14(8)$ \\
\hline Education Level & $* * * *$ & $* * * *$ & $* * * *$ & $* * * *$ & $* *$ & ND & $* * * *$ & $* *$ & $* * * *$ & $* * * *$ & ND \\
\hline $\begin{array}{l}\text { Elementary/ } \\
\text { High school }\end{array}$ & $36(33)$ & $29(13)$ & $18(7)$ & $8(8)$ & $7(5)$ & $4(1)$ & $13(5)$ & $9(4)$ & $8(3)$ & $29(12)$ & $14(8)$ \\
\hline $\begin{array}{l}\text { Professional/ } \\
\text { Postgraduate }\end{array}$ & $27.5(30)$ & $25(12)$ & $19(7)$ & $10(8)$ & $8(5)$ & $4(0)$ & $15(6)$ & $8(3)$ & $9(3)$ & $32(10)$ & $14(8)$ \\
\hline Occupation & $* * * *$ & $* * * *$ & $* *$ & $* *$ & ND & ND & $* * * *$ & $* * * *$ & $* * * *$ & $* * * *$ & ND \\
\hline $\begin{array}{l}\text { Student/ Work- } \\
\text { er }\end{array}$ & $34.5(32)$ & $29.5(13)$ & $18(8)$ & $9(9)$ & $7(6)$ & $4(1)$ & $13(5)$ & $9(5)$ & $8(3)$ & $30(11)$ & $14(8)$ \\
\hline Worker / Other & $25(28)$ & $23(13)$ & $20(7)$ & $10(8)$ & $7(5)$ & $4(0)$ & $15(5)$ & $8(3)$ & $9(3)$ & $31(9)$ & $14(8)$ \\
\hline Live with & ND & ND & ND & $* * * *$ & ND & ND & ND & ND & $\mathrm{ND}$ & ND & $* *$ \\
\hline Family & $29(29)$ & $26(14)$ & $19(8)$ & $10(8)$ & $7(6)$ & $4(0)$ & $14(5)$ & $8(4)$ & $8(3)$ & $31(11)$ & $14(8)$ \\
\hline $\begin{array}{l}\text { Alone or } \\
\text { Roommates }\end{array}$ & $35(30$ & $27(15)$ & $20(8)$ & $7(8)$ & $7(4)$ & $4(1)$ & $15(5)$ & $9(5)$ & $8(2)$ & $30(10)$ & $12(9)$ \\
\hline
\end{tabular}

Note: aKruskal Wallis; bDunntest with Bonferroni correction; ${ }^{* * * *} p<.0001 .{ }^{* * *} p<.001 .{ }^{* *} p<.01 .{ }^{*} p<.05$.

IQR - Interquartile range; PS - Perceived Stress; SSS - Seeking social support; TRL - Turning to Religion; HUM Humour; ADU - Alcohol-drug use; PAC - Planning and active coping; FEV - Focus on emotions and vent; PRI Positive reinterpretation; CR - Cognitive Reappraisal; ES - Expressive Suppression; TD - Total Difference; ND - No Differences. 
Table 5 shows that the most functional multivariate GLM to explain the Impact of the event during the quarantine period includes perceived stress, the coping strategies Alcohol-drug use,
Planning and active coping, and Focus on emotions and vent, the emotional regulation strategy Expressive Suppression, and living in Italy.

Table 4. Spearman correlation of Impact of Event with Perceived Stress, Coping Strategies, and Emotional Regulation.

\begin{tabular}{lll}
\hline & & Impact of Event \\
\hline & Perceived Stress & $.62^{* * *}$ \\
\cline { 2 - 3 } & Seeking social support & $.13^{* * *}$ \\
\cline { 2 - 3 } & Turning to religion & $-.08^{* *}$ \\
\cline { 2 - 3 } Coping Strategies & Alcour & -.00 \\
\cline { 2 - 3 } & Alcohol-drug use & $.25^{* * *}$ \\
\cline { 2 - 3 } & Planning and active coping & $-.09^{* *}$ \\
\cline { 2 - 3 } & Focus on emotions and vent & $.53^{* * *}$ \\
\cline { 2 - 3 } Emotional Regulation & Positive reinterpretation & $-.17^{* * *}$ \\
\cline { 2 - 3 } & Cognitive Reappraisal & $-.13^{* * *}$ \\
\cline { 2 - 3 } & Expressive Suppression & $.11^{* * *}$ \\
\hline
\end{tabular}

Note: ${ }^{* * *} p<.0001 .{ }^{* *} p<.01 .{ }^{*} p<.05$.

Table 5. Multivariate GLM of Impact of Event with Perceived Stress, 7 Coping Strategies, Emotional Regulation, and Country.

\begin{tabular}{|c|c|c|c|c|c|c|}
\hline Impact of Event & Coef. & $\begin{array}{l}\text { Standard } \\
\text { Error }\end{array}$ & $\mathbf{z}$ & $P>|z|$ & \multicolumn{2}{|c|}{ 95\% Conf. Interval } \\
\hline Perceived Stress & .92 & .06 & 14.7 & .001 & .80 & 1.04 \\
\hline \multicolumn{7}{|l|}{ Coping Strategies } \\
\hline Alcohol-drug use & .77 & .17 & 4.33 & .001 & .42 & 1.12 \\
\hline Planning and active coping & .49 & .12 & 4.03 & .001 & .25 & .73 \\
\hline Focus on emotions and vent & 1.9 & .19 & 10.07 & .001 & 1.54 & 2.28 \\
\hline \multicolumn{7}{|l|}{ Emotional Regulation } \\
\hline Expressive Suppression & .44 & .08 & 5.62 & .001 & .29 & .60 \\
\hline \multicolumn{7}{|l|}{ Country (Ref. Colombia) } \\
\hline Brazil & -.99 & 1.09 & -.91 & .364 & -3.15 & 1.15 \\
\hline Mexico & -.83 & 1.27 & -.66 & .512 & -3.32 & 1.65 \\
\hline Spain & 1.45 & 1.70 & .85 & .395 & -1.89 & 4.79 \\
\hline Italy & 4.75 & 1.34 & 3.47 & .001 & 2.07 & 7.43 \\
\hline
\end{tabular}

\section{DISCUSSIONS}

Results show statistically significant differences in all variables among countries. Although earlier studies have compared psychological aspects during quarantine and the COVID-19 pandemic in different countries $(7,28)$, not all of them have included the same countries or instruments as the present study. However, given that the orientations of the citizens of the same country tend to be shaped by a national culture (29), it is expected that there will be cross-cultural differences to assess stressors and implement coping strategies (30). Nevertheless, it is possible to argue that the differences among countries in the present study, in addition to cultural factors
(31), could be due to less restrictive and less clear containment, quarantine, and isolation measures in Latin America than in Europe (7, 32). For example, it can be observed that in Italy and Spain the state of alarm and the quarantine measures have lasted longer because there the outbreak occurred earlier than in Latin American countries, and to date, some restrictions still exist. Another crucial aspect is the term applied to the contagion containment measures and the effect that this can generate on the citizens' perception: in Italy, they were referred to as lockdown, in Spain as confinement, in Brazil as social distancing, in Colombia as preventive isolation and in Mexico as healthy distance. Despite these 
elements, it is important to continue analyzing how cultural factors can contribute to the success or failure of measures to contain the pandemic at a global level.

Regarding the sociodemographic characteristics, the medians of the impact of the event, perceived stress, and focus on emotions and vent are higher in women, people under 45 years, with low educational levels, and students. At the same time, seeking for social support and turning to religion is higher in women, adults over 45 years, with high educational level, being workers and other (housewives and pensioners), and the same for positive reinterpretation and cognitive reinterpretation, except for the gender for which there were no differences. On the other hand, the medians of humor are higher in men with a high educational level, while the consumption of alcohol or drugs is higher in young men. Planning is higher in adult men, people with a high educational level, workers, housewives, and pensioners. Finally, expressive suppression is higher in men who live with relatives. These results are consistent with those reported in previous studies $(2,33-35)$ which are explained by the characteristics of women's role in society, which implies an overload of responsibilities, in the workplace, at home, and in child and family care (36). On the other hand, within the age groups it was found that during the COVID-19 pandemic, stress levels were higher in people under 45 years of age (37), who, according to Salari et al. (9), are more concerned about the consequences at a professional and economic level. Furthermore, young people are more exposed to large amounts of information through social networks and media (38-40). Also, it may be hypothesized that younger people have not developed yet the emotional maturity to deal with situations of frustration. Another source of discomfort is the fact that their socialization and learning processes have been interrupted (41).

There are also differences in perceived stress between the educational levels since people with a low educational level tend to make more use of unreliable media and are more influenced by conspiracy theories $(39,40)$. Moreover, regarding occupation, there are differences between students and workers, and workers and others (i.e. housewives, unemployed, and retired people). Nonetheless, as reported in previous investigations (42), students were the most stressed category during quarantine. Despite quarantine and all the changes, it entailed from a professional viewpoint, causing an increase in the burden for a large part of the workers, it can be argued that being employed in these pandemic circumstances turns out to be a protective factor not only against possible financial losses, but it also can help maintain well-being, support among colleagues and sense of life (43).

The results about coping strategies and emotional regulation are similar to those reported by Eisenbarth (44) and Makarowski et al. (28) and can be explained according to Sica et al. (23), who stated that gender-related differences in the adoption of coping strategies can be attributed to differences in the stressful situations that are faced: as a matter of fact, women usually face more stressful circumstances associated with family care and health, while men deal with situations more related to work and financial difficulties. Concerning age groups, results are consistent with previous research demonstrating that young people tend to use less active coping strategies than adults (23). As regarding the educational and occupational level, it may be hypothesized that the use of some strategies may be associated with the age and the most used strategies in each group. Furthermore, these results are similar to the ones reported by Pieh et al. (45) and Prati (8) showing that adults under 35 years of age, women, the unemployed, people living alone, and with low-income present the most severe mental health problems.

To explain the association between the impact of the event with perceived stress, coping strategies, and emotional regulation, Lazarus and Folkman (46) proposed that there were two general types of coping with stress: the first, termed problem-focused, is aimed at doing something to solve the situation or modify the stress, whereas the second, the emotion-focused, is aimed at reducing the emotional distress. However, this does not mean that they are positive or negative. People sometimes use adaptive or non-adaptive strategies, and this may be linked to the fact that reactions to the same stimulus are different and may vary depending on circumstances. For example, social support is only a small part of the negative consequences of a stressful event, while personal coping resources can reduce its negative impact. On the other hand, the weak and moderate correlations 
in the present study can be explained according to the fact that people facing stressful experiences can deploy various coping strategies that may be theoretically considered mutually exclusive, and at a pragmatic level they may operate independently depending on the situation, context, timing, etc. (47), as found in our GLM.

The most functional model to predict perceived stress during quarantine includes different coping and emotional regulation strategies that should not be dichotomously considered, but should rather be interpreted according to the function they fulfill when used in a specific situation. Given that coping responses try to reduce the stressful situation (46), some reactions are more functional than others, such as the ones found in the present study aimed at directly facing the problem (planning and active coping). In contrast, those trying to mitigate the discomfort (drug or alcohol use, focus on emotion and vent, and expressive suppression), that may be better for well-being in the short term - for example during the quarantine period - although they are only fulfilling a merely palliative function without modifying the source of stress (48), in the long term, they can affect the quality of life and psychological well-being, since it has been found that people who make more use of avoidance strategies and who are focused on emotional distress, tend to present more mismatch that affects mental health $(8,23)$.

\section{CONCLUSIONS}

1. The results of the present research, which in turn corroborate previous studies, may contribute to the understanding why people react differently during quarantine across different countries, according to sociodemographic characteristics. However, when analyzing the differences in responses to quarantine, it must be considered that the evaluation of these variables was carried out at an individual and not collective level. Therefore, although an attempt has been made to group the results and to interpret them by using general theoretical models, individual differences should be either taken into account. Nevertheless, these results may help to identify the urgency of monitoring mental health in vulnerable groups such as the youth, students and women, in order to design specific prevention and intervention programs.

\section{CONFLICT OF INTERESTS}

The authors declare no conflict of interest.

\section{ACKNOWLEDGMENT}

The authors would like to express our appreciation to the researchers and the institutions that have participated in this multicentric study for their support in the design and dissemination of the questionnaire and the data collection. This study received financial support from the Universidad Cooperativa de Colombia within the call for projects "Proyectos para Implementación de Estrategias Institucionales con Aval de Instancias Rectorales 2020" (ID project 2781).

\section{REFERENCES}

1. Xiang YT, Yang Y, Li W, Zhang L, Zhang Q, Cheung $\mathrm{T}, \mathrm{Ng}$ CH. Timely mental health care for the 2019 novel coronavirus outbreak is urgently needed. The Lancet. 2020; 7(3): 228-229. doi:10.1016/S2215-0366(20)30046-8

2. Babore A, Lombardi L, Viceconti ML, Pignataro S, Marino V, Crudele M, et al. Psychological effects of the COVID-2019 pandemic: Perceived stress and

\section{ETHICAL APPROVAL}

The study was approved by the Bioethics Committee and the Faculty of Psychology of a Colombian University. It follows the international ethical guidelines for health research involving human beings of the Council for International Organizations of Medical Sciences (CIOMS) and the Declaration of Helsinki since the data collection has only been done through standardized questionnaires for this study and it is not intended to produce a psychological or psychiatric diagnosis.

coping strategies among healthcare professionals. Psychiatry Research. 2020; 293:113366, 11. doi:10.1016/j.psychres.2020.113366

3. Balmford B, Annan JD, Hargreaves JC, Altoè M, Bateman IJ. Cross-Country Comparisons of Covid19: Policy, Politics and the Price of Life. Environmental and Resource Economics. 2020; 76:525551. doi:10.1007/s10640-020-00466-5 
4. Brooks SK, Webster RK, Smith LE, Woodland L, Wessely S, Greenberg N, et al. The psychological impact of quarantine and how to reduce it: rapid review of the evidence. The Lancet. 2020; 395(10227):912-920. doi:10.1016/s0140-6736 (20)30460-8

5. Di Fronso S, Costa S, Montesano C, Di Gruttola F, Ciofi EG, Morgilli L, et al. The effects of COVID-19 pandemic on perceived stress and psychobiosocial states in Italian athletes. Interna-tional Journal of Sport and Exercise Psychology. 2020; doi:10.1080/1612197X.2020.1802612

6. Luo M, Guo L, Yu M, Jiang W, Wang H. The psychological and mental impact of coronavirus

disease 2019 (COVID-19) on medical staff and general public - A systematic review and metaanalysis. Psychiatry Research. 2020; 291:113190. doi:10.1016/j.psychres.2020.113190

7. Mækelæ MJ, Reggev N, Dutra N, Tamayo RM, Silva-Sobrinho RA, Klevjer K, et al. Perceived efficacy of COVID-19 restrictions, reactions and their impact on mental health during the early phase of the outbreak in six countries. Royal Society Open Science. 2020; 7:200644. doi:10.1098/rsos. 200644

8. Prati G. Mental health and its psychosocial predictors during national quarantine in Italy against the coronavirus disease 2019 (COVID-19). Anxiety, Stress, \& Coping. 2021; 34(2):145-156. doi: 10.1080/10615806.2020.1861253

9. Salari N, Hosseinian-Far A, Jalali R, Vaisi-Raygani A, Rasoulpoor S, Mohammadi M, et al. Prevalence of stress, anxiety, depression among the general population during the COVID-19 pandemic: a systematic review and meta-analysis. Global Health. 2020; 16(1):57. doi:10.1186/s12992-020-00589$\mathrm{w}$

10. Veer IM, Riepenhausen A, Zerban M, Wackerhagen C, Puhlmann L, Engen H, et al. Psycho-social factors associated with mental resilience in the Corona lockdown. PsyArXiv. 2020. doi:10.31234/ osf.io/4z62t

11. Sim K, Huak Chan Y, Chong PN, Chua HC, Wen Soon S. Psychosocial and coping responses within the community health care setting towards a national outbreak of an infectious disease. Journal of Psychosomatic Research. 2010; 68(2):195-202. doi:10.1016/j.jpsychores.2009.04.004

12. Main A, Zhou Q, Ma Y, Luecken LJ, Liu, X. Relations of SARS-related stressors and coping to Chinese college students' psychological adjustment during the 2003 Beijing SARS epidemic. Journal of Counseling Psychology. 2011; 58(3):410-423. doi:10.1037/a0023632

13. Khalid I, Khalid TJ, Qabajah MR, Barnard AG, Qushmaq IA. Healthcare workers emotions, perceived stressors and coping strategies during a MERS-CoV outbreak. Clinical Medicine \& Research.
2016; 14(1):7-14. doi:10.3121/cmr.2016.1303

14. Wang C, Pan R, Wan X, Tan Y, Xu L, Ho CS, et al. Immediate Psychological Responses and Associated Factors during the Initial Stage of the 2019 Coronavirus Disease (COVID-19) Epidemic among the General Population in China. International Journal of Environmental Research and Public Health. 2020; 17(5):1729. doi:10.3390/ijerph 17051729

15. Rubin GJ, Wessely S. The psychological effects of quarantining a city. British Medical Journal. 2020; 368: m313. doi:10.1136/bmj.m313

16. Báguena MJ, Villarroya E, Beleña A, Díaz A, Roldán C, Reig R. Propiedades Psicométricas de la Versión Española de la escala Revisada de Impacto del Estresor. Análisis y Modificación de Conducta. 2001; 27:581-604.

17. Caiuby AVS, Lacerda SS, Quintana MI, Torii TS, Andreoli SB. Adaptação transcultural da versão brasileira da Escala do Impacto do EventoRevisada (IES-R). Cadernos de Saúde Pública. 2012; 28:597-603.

18. Craparo G, Faraci P, Rotondo G, Gori A. The Impact of Event Scale - Revised: psychometric properties of the Italian version in a sample of flood victims. Neuropsychiatric Diseases and Treatment. 2013; 9:1427-32. doi: 10.2147/NDT.S51793. Epub 2013 Sep 19. PMID: 24092980; PMCID: PMC3788700.

19. Remor E. Psychometric Properties of a European Spanish Version of the Perceived Stress Scale (PSS). The Spanish Journal of Psychology. 2006; 9(1):86-93. doi:10.1017/S1138741600006004

20. Luft CDB, Sanches SDO, Mazo GZ, Andrade A. Versão brasileira da Escala de Estresse Percebido: tradução e validação para idosos. Revista de Saúde Pública. 2007; 41(4):606-615. doi:10.1590/S0034-89102007000400015

21. Mondo C, Sechi C, Cabras C. Psychometric evaluation of three versions of the Italian Perceived Stress Scale. Current Psychology. 2019; 1-9. doi:10.1007/s12144-019-0132-8

22. Crespo M, Cruzado JA. La evaluación del afrontamiento: adaptación española del cuestionario COPE con una muestra de estudiantes universitarios. Análisis y Modificación de Conducta. 1997; 23:797-830.

23. Sica C, Magni C, Ghisi M, Altoe G, Sighinolfi C, Chiri LR, et al. Coping Orientation to Problems Experienced-Nuova Versione Italiana (COPENVI): Uno strumento per la misura degli stili di coping. Psicoterapia Cognitiva e Comportamentale. 2008; 14(1):27-53.

24. Rodríguez-Carvajal R, Moreno-Jiménez B, Garrosa E. Cuestionario de Regulación Emocional. Versión española. Madrid: Universidad Autónoma de Madrid; 2006. 
25. Balzarotti S, John OP, Gross JJ. An Italian Adaptation of the Emotion Regulation Questionnaire. European Journal of Psychological Assessment. 2010; 26(1):61-67. doi:10.1027/ 1015-5759/ a000009

26. Boian AC, Soares DSM, Silva J. Questionário de Regulação Emocional adaptado para a população brasileira. 2009. Available from: http://spl. stanford.edu/pdfs/erq_portuguese_brazilian.pdf

27. Bland JM, Altman DG. Cronbach's alpha. British Medical Journal. 1997; 314(7080):572. doi:10.1136/bmj.314.7080.572

28. Makarowski R, Piotrowski A, Predoiu R, Görner K, Predoiu A, Mitrache G, et al. Stress and coping during the COVID-19 pandemic among martial arts athletes - A cross-cultural study. Archives of Budo. 2020; 16: 161-171.

29. De Vaus J, Hornsey MJ, Kuppens P, Bastian B. Exploring the east-west divide in prevalence of affective disorder: A case for cultural differences in coping with negative emotion. Personality and Social Psychology Review. 2018; 22(3):285-304. doi:10.1177/1088868317736222

30. Wong PTP, Wong LCJ., editors. Handbook of multicultural perspectives on stress and coping. New York: Springer; 2006.

31. Chun CA, Moos RH, Cronkite RC. Culture: A Fundamental Context for the Stress and Coping Paradigm. In: Wong PTP, Wong LCJ. (eds.). Handbook of Multicultural Perspectives on Stress and Coping. International and Cultural Psychology. Boston, MA: Springer; 2006. p. 29-53 Available from: doi:10.1007/0-387-26238-5_2

32. Guan Y, Deng H, Zhou X. Understanding the impact of the COVID-19 pandemic on career development: Insights from cultural psychology. Journal of Vocational Behavior. 2020; 119:103438. doi:10.1016/j.jvb.2020.103438

33. Broche-Pérez Y, Fernández-Fleites Z, JiménezPuig E, Fernández-Castillo E, Rodríguez-Martin BC. Gender and Fear of COVID-19 in a Cuban Population Sample. International Journal of Mental Health and Addiction. 2020; 1-9. doi:10.1007/s11469-020-00343-8

34. Qiu J, Shen B, Zhao M, Wang Z, Xie B, Xu Y. A nationwide survey of psychological distress among Chinese people in the COVID-19 epidemic: Implications and policy recommendations. General Psychiatry. 2020; 33(2):e100213. doi:10.1136/ gpsych-2020-100213

35. Rossi R, Socci V, Talevi D, Mensi S, Niolu C, Pacitti $\mathrm{F}$, et al. COVID-19 pandemic and lockdown measures impact on mental health among the general population in Italy. Frontiers in psychiatry. 2020; 11:790. doi:10.3389/fpsyt.2020.00790

36. Alon TM, Doepke M, Olmstead-Rumsey J, Tertilt M. The impact of COVID-19 on gender equality. National Bureau of Economic Research. 2020. doi:10.3386/w26947.

37. Dai H, Zhang SX, Looi KH, Su R, Li J. Perception of Health Conditions and Test Availability as Predictors of Adults' Mental Health during the COVID19 Pandemic: A Survey Study of Adults in Malaysia. International Journal of Environmental Research and Public Health. 2020; 17:5498. doi:10.3390/ijerph17155498

38. Garfin DR. Technology as a coping tool during the coronavirus disease 2019 (COVID-19) pandemic: Implications and recommendations. Stress and Health. 2020; 36(4):555-559. doi:10.1002/smi. 2975

39. Hossain MM, Tasnim S, Sultana A, Faizah F, Mazumder H, Zou L, et al. Epidemiology of mental health problems in COVID-19: A review. F1000Research. 2020; 9:636. doi:10.12688/ f1000research.24457.1

40. Martínez-Taboas A. Pandemias, COVID-19 y Salud Mental: Qué Sabemos Actualmente?. Revista Caribeña de Psicología. 2020; 4(2):143-152. doi:10. 37226/rcp.v4i2.4907

41. Sun QH, Su Y. Psychological crisis intervention for college students during novel coronavirus infection epidemic. Psychiatry Research. 2020;289: 113043. doi:10.1016/j.psychres.2020. 113043

42. Odriozola-González P, Planchuelo-Gómez Á, Irurtia MJ, de Luis-García R. Psychological effects of the COVID-19 outbreak and lockdown among students and workers of a Spanish university. Psychiatry Research. 2020; 290:113108. doi:10.1016/j.psychres.2020.11310

43. Crayne MP. The traumatic impact of job loss and job search in the aftermath of COVID-19. Psychological Trauma: Theory, Research, Practice, and Policy. 2020; 12(S1):S180-S182. doi:10.1037/ tra0000852

44. Eisenbarth CA. Coping with Stress: Gender Differences among College Students. College Student Journal. 2019; 53(2):151-162.

45. Pieh C, Budimir S, Probst T. The effect of age, gender, income, work, and physical activity on mental health during coronavirus disease (COVID-19) lockdown in Austria. Journal of Psychosomatic Research. 2020; 136:110186. doi:10.1016/j.jpsychores.2020.110186

46. Lazarus RS. Estrés y Emoción. Manejo e implicaciones en nuestra salud. Bilbao, España: Desclée de Brouwer; 2000.

47. Cheng C, Lau HPB, Chan MPS. Coping flexibility and psychological adjustment to stressful life changes: A meta-analytic review. Psychological Bulletin. 2014; 140(6):1582-1607. doi:10.1037/ a0037913

48. Carver CS, Scheier MF, Weintraub JK. Assessing coping strategies: A theoretically based approach. Journal of Personality and Social Psychology. 1989; 56:267-283. doi:10.1037//0022-3514.56.2.267 
Date of receipt of the manuscript: $21 / 06 / 2021$

Date of receipt of the manuscript: 24/09/2021

Erika Yohanna BEDOYA CARDONA, ORCID ID: 0000-0002-3398-8188; SCOPUS Author ID: 55841539000 Ioana POPA, ORCID ID: 0000-0002-9534-2083; SCOPUS Author ID: 55987923500

Anna MORANDI, ORCID ID: 0000-0003-0573-9421; SCOPUS Author ID: 8438910700

Cristina MONTOMOLI, ORCID ID: 0000-0002-8526-5846, SCOPUS Author ID: 6603687469 